\title{
UJI EFEK INFUSA BUAH MAHKOTA DEWA (Phaleria Macrocarpa Scheff Boer) TERHADAP PENCEGAHAN PENINGKATAN KOLESTEROL DARAH PADA TIKUS PUTIH JANTAN (RattuS Novergicus) YANG DIBERI DIET LEMAK TINGGI
}

\author{
Julizar $^{1}$, Lili Irawati ${ }^{1}$, Erlina Rustam ${ }^{2}$ \\ 1. Bagian Fisika Kedokteran Fakultas Kedokteran Universitas Andalas \\ 2. Bagian Farmakologi dan Terapi Fakultas Kedokteran Universitas Andalas \\ email : julizar.nzr@gmail.com
}

\section{Abstrak}

Penyakit jantung koroner (PJK) merupakan penyebab utama kematian di berbagai belahan dunia termasuk di Indonesia. Salah satu pemicu terjadinya PJK adalah tingginya kadar kolesterol dalam darah. Buah mahkota dewa telah lama digunakan oleh masarakat untuk menurunkan kadar kolesterol dan mengobati berbagai penyakit kardiovaskuler.

Telah dilakukan penelitian untuk melihat efek infus buah mahkota dewa terhadap pencegahan peningkatan kadar kolesterol pada tikus putih jantan yang diberi diet lemak tinggi (DLT). Penelitian ini menggunakan 30 ekor Rattus novergicus jantan yang berumur 2,5 - 3 bulan dengan berat badan 250 - 350 gram. Hewan coba dibagi secara acak atas lima kelompok dan diperlakukan sebagai berikut:

Kelompok I diberi diet standar 555 global feed dan $1 \mathrm{ml}$ aquades, kelompok II diberi diet lamak tinggi(DLT) yang terdiri dari 2\% Kolesterol, 10\% kuning telur itik, $18 \%$ lemak sapi dan $78 \%$ diet standar dan $1 \mathrm{ml}$ aquades, kelompok III diberi DLT dan $1 \mathrm{ml}$ infus yang mengandung $97 \mathrm{mg}$ mahkota dewa., kelompok IV diberi DLT dan $1 \mathrm{ml}$ infus yang mengandung $194 \mathrm{mg}$ mahkota dewa, kelompok $\mathrm{V}$ diberi DLT dan $1 \mathrm{ml}$ infus yang mengandung $388 \mathrm{mg}$ mahkota dewa. Infus diberikan per oral setiap hari selama 56 hari. Diet dan air minum diberikan ad libitum.

Pada hari ke 0, 14, 28, 42 dan 56 darah diambil melalui vena centralis ekor untuk ditentukan kadar kolesterol totalnya secara enzimatik menggunakan KIT kolesterol CHOD-PAP merk Diasys. Absorbans diukur dengan spektrofotometer Genesis 20 pada panjang gelombang $546 \mathrm{~nm}$. Data dianalisis dengan GLM pengukuran berulang dan one-way anova.

Hasil penelitian menunjukan : pemberian infus yang mengandung 97, 194 dan 388 mg mahkota dewa dapat mencegah peningkatan kadar kolesterol dibanding kontrol (-). Terdapat perbedaan yang signifikan $(\mathrm{p}<0,05)$ antara kelompok 194 dan $388 \mathrm{mg}$ dengan kelompk $97 \mathrm{mg}$, dimana kelompok 194 dan $388 \mathrm{mg}$ mencegah peningkatan lebih besar. Tidak terdapat perbedaan $(p>0,05)$ antara kelompok yang mendapat 194 dengan kelompok yang mendapat 388 mg mahkota dewa. 
Disarankan untuk meneliti efek pencegahan peningkatan pada profil lipid yang lain dan melihat efek penurunan infus mahkota dewa pada hewan coba yang hiperkolesterolemik.

Kata kunci : Mahkota dewa, kolesterol

\begin{abstract}
Coronary heart disease (CHD) is the leading cause of death in many parts of the world including in Indonesia. One of the triggers of CHD are high blood cholesterol levels. The Crown of God (Phaleria macrocarpa) has long been used by people to lower cholesterol and treat various cardiovascular diseases. Has done research to observe the effect of infusion Phaleria to prevent an increase in cholesterol levels in male white rats fed a high fat diet (HFD). This study used 30 male Rattus novergicus old from 2.5 to 3 months with body weight 250-350 grams. Experimental animals were randomized over five groups and treated as follows:

Group I was given a standard diet 555 of global feed and $1 \mathrm{ml}$ aquades, group II were given a diet high fat (HFD) consisting of $2 \%$ cholesterol, $10 \%$ of duck egg yolk, beef $18 \%$ fat and $78 \%$ standard diet and $1 \mathrm{ml}$ aquades, group III was given the DLT and $1 \mathrm{ml}$ infusion containing $97 \mathrm{mg}$ of crown gods., group IV were given DLT and $1 \mathrm{ml}$ infusion containing $194 \mathrm{mg}$ crown of god, group V were given HFD and $1 \mathrm{ml}$ infusion containing $388 \mathrm{mg}$ the crown of god. Infusion given orally every day for 56 days. Diet and drinking water provided ad libitum.

On days $0,14,28,42$ and 56 blood was collected via the tail vein centralis for total cholesterol is determined enzymatically using cholesterol Chod-PAP KIT Diasys. Absorbance was measured with a spectrophotometer Genesis 20 at 546 $\mathrm{nm}$ wavelength. Data were analyzed by GLM repeated measurements and oneway ANOVA.

The results showed: the infusion containing 97, 194 and $388 \mathrm{mg}$ crown of god can prevent an increase in cholesterol levels compared to controls (-).There are significant differences ( $\mathrm{p}<0.05$ ) between groups 194 and $388 \mathrm{mg}$ with $97 \mathrm{mg}$ faction, which groups 194 and $388 \mathrm{mg}$ prevent the increase is greater. No difference $(p>0.05)$ between the group receiving 194 with the group receiving $388 \mathrm{mg}$ crown of gods.

It is advisable to examine the effect of preventing an increase in other lipid profiles and observe the effect of decreasing infusion crown of gods on hypercholesterolemic animal.

Key word : Phaleria macrocarpa, cholseterol
\end{abstract}




\section{Pendahuluan}

Penyakit jantung koroner (PJK) sampai saat ini masih merupakan penyebab kematian utama di berbagai benua mulai dari Amerika Utara, Eropa dan Asia termasuk Indonesia. Meskipun sudah digunakan bermacam strategi farmakologis dan perubahan gaya hidup, namun dari tahun ke tahun angka penderitanya selalu cenderung meningkat. ${ }^{(1)}$

Di Indonesia, prevalensi PJK juga mengalami trend yang sama yakni semakin bertambahnya jumlah penderita. Survei Kesehatan Rumah Tangga (SKRT) yang dilakukan secara berkala oleh Departemen Kesehatan menunjukkan, penyakit jantung memberikan kontribusi sebesar $19,8 \%$ dari seluruh penyebab kematian pada tahun 1993. Angka tersebut meningkat menjadi 24,4 persen pada tahun 1998. Hasil SKRT tahun 2001, PJK telah menempati urutan pertama dalam deretan penyebab utama kematian di Indonesia. ${ }^{(2)}$

Studi epidemiologi telah membuktikan bahwa faktor risiko PJK di antaranya adalah merokok, kadar kolesterol total dan kolesterol low density lipoprotein (LDL) yang tinggi dan kolesterol high density lipoprotein (HDL) yang rendah, hipertensi, diabetes mellitus (DM) dan usia lanjut. ${ }^{(3)}$ Faktorfaktor risiko tersebut bersifat independen dan aditif. Artinya, semakin banyak faktor risiko, semakin besar risiko bermanifestasi menderita penyakit aterosklerosis.

Ditinjau dari segi kadar lipid darah untuk mencegah terjadinya PJK, upaya yang dapat dilakukan adalah mengendalikan kadar lipid darah ke keadaan normal. Dari segi pembiayaan, pengobatan atau pencegahan untuk mengendalikan kadar lipid darah (khususnya kolesterol total dan LDL) menjadi normal dengan obat-obatan modern relatif cukup mahal, disamping itu juga dapat menimbulkan efek samping yang cukup serius. Untuk itu perlu dicari obat alternatif yang cukup murah dan relatih aman.

Tanaman mahkota dewa (Phaleria macrocarpa Scheff Boerl) adalah salah satu tanaman asli Indonesia yang akhirakhir ini popular sebagai tanaman yang secara empiris dapat mengobati berbagai macam penyakit. Beberapa manfaat mahkota dewa berdasarkan berbagai pengalaman masyarakat dan testimoni yang terdapat diberbagai media massa baik cetak maupun elektronik, mahkota dewa antara lain berkhasiat sebagai : anti kanker, antioksidan, antihistamin/anti-alergi, hipoglikemik (penurun gula darah), hepatoprotektor, anti radang(anti inflamasi), anti bakteri, anti piretik (menurunkan panas), analgesic (mengurangi rasa sakit), menurunkan kadar asam urat, kardiovaskuler (efek pada jantung, hipertensia, diuretic), efek anti kejang, efek penenang, antiobesitas dan anti hypercholesterolemia.

Berbagai penelitian untuk menguji khasiat mahkota dewa telah banyak dilakukan diantaranya : rebusan buah Mahkota Dewa berkhasiat sebagai imunostimulan, ${ }^{(4)}$ biji mahkota dewa berkhasiat terhadap beberapa mikroba penyebab infeksi kulit, ${ }^{(5)}$ daging buah mahkota dewa dapat menurunkan glukosa darah kelinci jantan new zealand yang dibebani glukosa oral. ${ }^{(6)}$ Biji mahkota dewa juga berefek terhadap ekspresi caspase-3 aktif pada cel line ca colon widr. ${ }^{(7)}$ Sepanjang penelusuran pustaka yang penulis lakukan, laporan tentang uji efek rebusan buah mahkota dewa sebagai anti kolesterol belum ditemukan meskipun tanaman ini dikatakan berkhasiat sebagai antiobesitas, antikolesterol dan mencegah aterosklerosis. ${ }^{(8)}$ Penelitian ini bertujuan untuk mendapatkan data tentang efek infusa buah mahkota dewa 

PENINGKATAN KOLESTEROL DARAH PADA TIKUS PUTIH JANTAN (Rattus Novergicus) YANG DIBERI DIET LEMAK TINGGI

terhadap penghambatan peningkatan kadar kolesterol pada hewan coba yang diberi diet lemak tinggi.

\section{METODE PENELITIAN}

1. Jenis Penelitian Eksperimental pretest - post test design

2. Waktu dan Tempat penelitian : Peneltian ini dimulai dari bulan Maret 2011 dan selesai bulan September 2011. Dilakukan di Lab Farmakologi fakultas Farmasi Universitas Andalas.

3. Bahan penelitian : berupa daging buah mahkota dewa yang telah dikeringkan yang telah diperjual belikan di pasaran. Kit Kolesterol CHOD-PAP produk Diasys.

4. Alat penelitan : Spektrofotometer Genesis 20, mikropipet, vortex, sentrifus, jarum oral, spuit, tabung rekasi, timbangan triple beam type MB2610, termometer dan kandang hewan.

5. Sabjek Penelitian : Tikus putih jantan (Rattus novergicus) yang berumur kurang $2-3$ bulan dengan berat badan lebih kurang 250 - 350 gram. Diperoleh dari laboratorium Farmakologi Fakultas Farmasi Unand. Jumlah subjek penelitian dihitung dengan menggunakan rumus:

$(\mathrm{t}-1)(\mathrm{r}-1) \geq 15 \quad$ (Hanafiah, 1997) :

$\mathrm{T}=$ Jumlah kelompok hewan coba

$\mathrm{r}=$ Jumlah hewan coba masing-masing kelompok
Pada penelitian ini jumlah kelompok hewan coba (t) adalah 5 kelompok, maka didapat jumlah hewan coba pada masing-masing kelompok (r) $r \geq 5$. Pada peneltitian jumlah hewan : coba yang digunakan adalah 6 ekor per kelompok.

\section{Cara Penelitian \\ a. Pembuatan sediaan Infusa mahkota dewa.}

Pada penelitian ini digunakan 3 peringkat dosis yaitu; dosis I, II dan III masing-masing 97, 194 dan $388 \mathrm{mg} / \mathrm{ml}$ infusa. Cara penyiapan infusa: Timbang 3,88 gram daging buah mahkota dewa yang telah kering, cuci bersih dengan air mengalir, tambahkan 3 liter aquades, panaskan sampai mendidih, biarkan selama 15 menit. Dinginkan dan saring dengan kertas saring. Selanjutnya dipekatkan sampai tinggal $1 / 3$ nya dengan penangas air pada suhu tidak lebih $50 \quad{ }^{0} \mathrm{C}$. Terakhir dicukupkan dengan akuades sampai volume 1 liter (1 $\mathrm{ml}$ mengadung $388 \mathrm{mg}$ MD). Pisahkan $500 \mathrm{ml}$ untuk perlakuan III (2 $\mathrm{X}$ dosis). Sisanya ditambahkan aquades $500 \mathrm{ml}$ lagi $(1 \mathrm{ml}$ setara mengandung $194 \mathrm{mg}$ MD). Pisahkan lagi $500 \mathrm{ml}$ untuk perlakuan II. Sisa pengenceran ini ditambahkan lagi $500 \mathrm{ml}$ aquades $(1 \mathrm{ml}$ mengadung $97 \mathrm{mg}$ Mahkota Dewa) untuk perlakuan I (1/2 dosis).

\section{b. Penyiapan diet lemak tinggi.}

Pembuatan diet lamak tinggi (DLT) dibuat dengan cara mencampur makanan standar 70\%, lemak sapi $18 \%$, kuning telur itik $10 \%$ dan kolesterol $2 \%$. Kuning telur yang telah direbus dipisahkan dari putih telurnya lahu diblender sampai halus. Kolesterol dan lemak sapi dipanaskan hingga cair dengan suhu tidak lebih dari $40^{\circ} \mathrm{C}$, tambahkan kuning telur yang telah di blender tadi aduk hingga rata. 
Selanjutnya tambahkan makanan stan- berian infusa mahkota dewa diberikan dar, aduk hingga rata kemudian di- setiap harinya pada waktu yang sama.

dinginkan. Makanan lemak tinggi dibuat untuk kebutuhan setiap 3 hari. Makanan standar adalah makanan ikan terapung merk Global feed 555 berupa pelet yang terdiri dari komposisi: protein kasar minimum: $18 \%$, lemak kasar minimum $4 \%$, serat kasar minimum $6 \%$, Abu maksimum $13 \%$ dan kadar air maksimum $12 \%$.

\section{c. Perlakuan pada hewan coba}

Hewan coba sebelum digunakan terlebih dulu diaklitimasi lebih kurang satu minggu, ditempatkan di kandang yang berukuran 40 X 30 X $20 \mathrm{~cm}$. Setiap kandang berisi 1 ekor hewan coba. Setelah proses aklitimasi, hewan coba dibagi secara acak menjadi 5 kelompok, setiap kelompok terdiri dari 6 ekor hewan coba. Selanjutnya diperlakuan sebagai berikut :

Kelompok I : Blangko, diberi diet standar dan $1 \mathrm{ml}$ aquades.

Kelompok II : Kontrol (-), diberi DLT dan $1 \mathrm{ml}$ aquades.

Kelompok III : Perlakuan I (P1), diberi DLT dan $1 \mathrm{ml}$ infusa setara $97 \mathrm{mg}$ MD

Kelompok IV : Perlakuan II (P2), diberi DLT dan $1 \mathrm{ml}$ infusa setara 194 MD.

Kelompok V : Perlakuan III (P3), diberi DLT dan $1 \mathrm{ml}$ infusa setara 388 MD 2.

Hewan coba diberi makan dan minum ad libitum. Sisa makan ditimbang setiap 14 hari saat akan dipuasakan untuk mengetahui jumlah makan yang dikonsumsi setiap kelompoknya. Pem-

\section{d. Pengambilan darah hewan Coba.}

Sebelum darah hewan coba diambil, hewan coba terlebih dipuasakan kurang lebih $16-18$ jam tetapi tetap diberi air minum. Darah diambil dengan cara menoreh vena sentralis ekor kurang lebih $0,5-1 \mathrm{ml}$. Selanjutnya darah disentrifus dengan kecepatan 5000 rpm selama 5 menit. Serum dipisahkan untuk ditentukan kadar kolesterolnya. Pengambilan darah dilakukan pada hari ke 0 , 14, 28, 42 dan 56.

e. Penetapan Kolesterol hewan coba.

Pengukuran kadar kolesterol hewan coba ditetapkan dengan metoda enzimatik mengikuti prosedur yang tertera pada Kit CHOD-PAP produk Diasys menggunakan Spektrofotometer Genesis 20 buatan Jerman.

\section{f. Pengolahan data}

Untuk melihat perbedaan pengaruh perlakuan antar kelompok data diolah dengan menggunakan statistik Anova. Sedangkan untuk melihat pengaruh lama waktu perlakuan pada masing-masing kelompok dilakukan analisis General Linear Model repeated Measurment.

\section{Hasil dan Pembahasan.}

\section{A. Penetapan kolesterol total hewan coba.}

Penetapan kolesterol total hewan coba selama perlakuan diringkas pada tabel 1 . 
DEWA (Phaleria Macrocarpa Scheff Boerl) TERHADAP PENCEGAHAN PENINGKATAN KOLESTEROL DARAH PADA TIKUS PUTIH JANTAN (Rattus Novergicus) YANG DIBERI DIET LEMAK TINGGI

Tabel 1. Ringkasan hasil penetapan kolesterol total selama perlakuan

\begin{tabular}{clrrrrr}
\hline Kel perlakuan & & $\begin{array}{c}\mathrm{K}_{0} \\
(\mathrm{mg} / \mathrm{dL})\end{array}$ & $\begin{array}{c}\mathrm{K}_{14} \\
(\mathrm{mg} / \mathrm{dL})\end{array}$ & $\begin{array}{c}\mathrm{K}_{28} \\
(\mathrm{mg} / \mathrm{dL})\end{array}$ & $\begin{array}{c}\mathrm{K}_{42} \\
(\mathrm{mg} / \mathrm{dL})\end{array}$ & $\begin{array}{c}\mathrm{K}_{56} \\
(\mathrm{mg} / \mathrm{dL})\end{array}$ \\
\hline \multirow{3}{*}{ Blanko } & Rata-rata & 86,41 & 85,73 & 90,08 & 88,04 & 87,10 \\
& Std. deviasi & 3,00 & 2,90 & 5,14 & 1,95 & 2,96 \\
& Rata-rata & 94,04 & 148,56 & 191,57 & 225,42 & 251,30 \\
Kontrol (-) & Std. deviasi & 6,87 & 8,71 & 6,17 & 12,18 & 13,07 \\
Perlakuan I & Rata-rata & 89,11 & 122,58 & 133,24 & 139,62 & 147,30 \\
& Std. deviasi & 6,70 & 13,45 & 14,71 & 15,39 & 12,89 \\
Perlakuan II & Rata-rata & 95,16 & 108,85 & 116,15 & 122,11 & 126,77 \\
& Std. deviasi & 15,97 & 14,13 & 14,78 & 14,19 & 14,29 \\
Perlakuan III & Rata-rata & 85,80 & 97,16 & 104,10 & 109,64 & 113,41 \\
& Std. deviasi & 2,68 & 2,94 & 2,84 & 3,42 & 3,73 \\
\hline \multirow{2}{*}{$\mathrm{n}=6$} & & & & & &
\end{tabular}

Untuk melihat efek penghambatan dihitung dari seberapa banyak peningkatan kadar kolesterol setiap 14 hari dengan kadar waktu 0 (K0) sebagai acuan. Peningkatan kolestrol hewan coba setiap 14 hari dihitung dengan persamaan :

$$
\text { Peningkatan } \mathrm{K}_{\mathrm{n}}=\mathrm{K14}_{\mathrm{n}}-\mathrm{K}_{\mathbf{0}}(\mathrm{mg} / \mathrm{dl})
$$

$\mathrm{K} 14_{\mathrm{n}}=$ kolesterol hewan coba pada 14 hari I (K14), II (K28), III(K42) dan IV(K56). Peningkatan kadar kolesterol hewan coba pada masing-masing kelompok perlakuan disajikan pada tabel 2 .

Tabel 2. Peningkatan kolesterol hewan coba selama perlakuan (mg/dL)

\begin{tabular}{|c|c|c|c|c|c|c|}
\hline Kel perlakuan & & $\begin{array}{c}\uparrow K 0 \\
(\mathrm{mg} / \mathrm{dL}) \\
\end{array}$ & $\begin{array}{c}\uparrow \mathrm{K} 14 \\
(\mathrm{mg} / \mathrm{dL})\end{array}$ & $\begin{array}{r}\uparrow \mathrm{K} 28 \\
(\mathrm{mg} / \mathrm{dL})\end{array}$ & $\begin{array}{r}\uparrow \mathrm{K} 42 \\
(\mathrm{mg} / \mathrm{dL})\end{array}$ & $\begin{array}{c}\uparrow \mathrm{K} 56 \\
(\mathrm{mg} / \mathrm{dL})\end{array}$ \\
\hline \multirow{2}{*}{ Blanko } & Rata-rata & 0,00 & $-0,68$ & 3,68 & 1,63 & 0,70 \\
\hline & Std. deviasi & 0,00 & 1,48 & 2,77 & 2,46 & 1,46 \\
\hline \multirow{2}{*}{ Kontrol (-) } & Rata-rata & 0,00 & 54,52 & 97,53 & 131,38 & 157,26 \\
\hline & Std. deviasi & 0,00 & 5,10 & 6,22 & 8,68 & 9,68 \\
\hline \multirow{3}{*}{ Perlakuan I } & Rata-rata & 0,00 & 33,47 & 44,13 & 50,51 & 58,19 \\
\hline & Std. deviasi & 0,00 & 6,95 & 8,18 & 8,87 & 8,73 \\
\hline & Rata-rata & 0,00 & 13,69 & 21,00 & 26,96 & 31,61 \\
\hline \multirow[t]{2}{*}{ Perlakuan II } & Std. deviasi & 0,00 & 2,06 & 1,34 & 1,91 & 1,95 \\
\hline & Rata-rata & 0,00 & 11,36 & 18,30 & 23,84 & 27,61 \\
\hline Perlekuan III & Std. deviasi & 0,00 & 1,52 & 1,83 & 2,18 & 2,30 \\
\hline
\end{tabular}

Persentase peningkatan kolesterol masing-masing hewan coba dihitung dengan persamaan:

$$
\% \text { peningka } \tan \text { kolesterol }=\frac{K 14_{n}-K 0}{K 0} \times 100 \%
$$

Hasilnya disajikan pada tabel 3.

Tabel 3. Persentase peningkatan kolesterol hewan coba selama perlakuan 


\begin{tabular}{clcrrrrr}
\hline \multirow{3}{*}{ Kel perlakuan } & & $\uparrow$ K0 & $\uparrow$ K14 & $\uparrow$ K28 & $\uparrow$ K42 & $\uparrow$ K56 \\
\cline { 2 - 7 } & & \multicolumn{1}{c}{$(\%)$} & \multicolumn{1}{c}{$(\%)$} & \multicolumn{1}{c}{$(\%)$} & \multicolumn{1}{c}{$(\%)$} & \multicolumn{1}{c}{$(\%)$} \\
\hline Blamko & Rata-rata & 0.00 & $-\mathbf{0 , 7 7}$ & $\mathbf{4 , 2 0}$ & $\mathbf{1 , 9 5}$ & $\mathbf{0 , 8 2}$ \\
& Std. deviasi & 0.00 & $\mathbf{1 , 6 8}$ & $\mathbf{3 , 2 0}$ & $\mathbf{2 , 9 3}$ & $\mathbf{1 , 7 6}$ \\
& Rata-rata & 0.00 & $\mathbf{5 8 , 2 2}$ & $\mathbf{1 0 4 , 4 2}$ & $\mathbf{1 4 0 , 2 0}$ & $\mathbf{1 6 7 , 8 4}$ \\
Kontrol (-) & Std. deviasi & 0.00 & 6,66 & $\mathbf{1 2 , 9 0}$ & $\mathbf{1 2 , 3 0}$ & $\mathbf{1 4 , 2 6}$ \\
Perlakuan I & Rata-rata & 0.00 & $\mathbf{3 7 , 2 8}$ & $\mathbf{4 9 , 2 1}$ & $\mathbf{5 6 , 3 5}$ & $\mathbf{6 5 , 4 0}$ \\
& Std. deviasi & 0.00 & $\mathbf{5 , 2 8}$ & $\mathbf{5 , 8 3}$ & $\mathbf{6 , 0 9}$ & $\mathbf{9 , 8 2}$ \\
& Rata-rata & 0.00 & $\mathbf{1 4 , 9 8}$ & $\mathbf{2 2 , 7 4}$ & $\mathbf{2 9 , 2 3}$ & $\mathbf{3 4 , 2 3}$ \\
Perlakuan II & Std. deviasi & 0.00 & $\mathbf{4 , 4 4}$ & $\mathbf{4 , 9 2}$ & $\mathbf{6 , 5 3}$ & $\mathbf{7 , 3 7}$ \\
Perlakuan III & Rata-rata & 0.00 & $\mathbf{1 3 , 2 6}$ & $\mathbf{2 1 , 3 6}$ & $\mathbf{2 7 , 8 1}$ & $\mathbf{3 2 , 1 9}$ \\
& Std. deviasi & 0.00 & $\mathbf{1 , 8 8}$ & $\mathbf{2 , 4 4}$ & $\mathbf{2 , 7 7}$ & $\mathbf{2 , 8 3}$ \\
\hline n =6 & & & & & &
\end{tabular}

Grafik peningkatan kadar kolesterol hewan coba di sajikan pada gambar 1.

\section{Estimated Marginal Means of kolesterol}
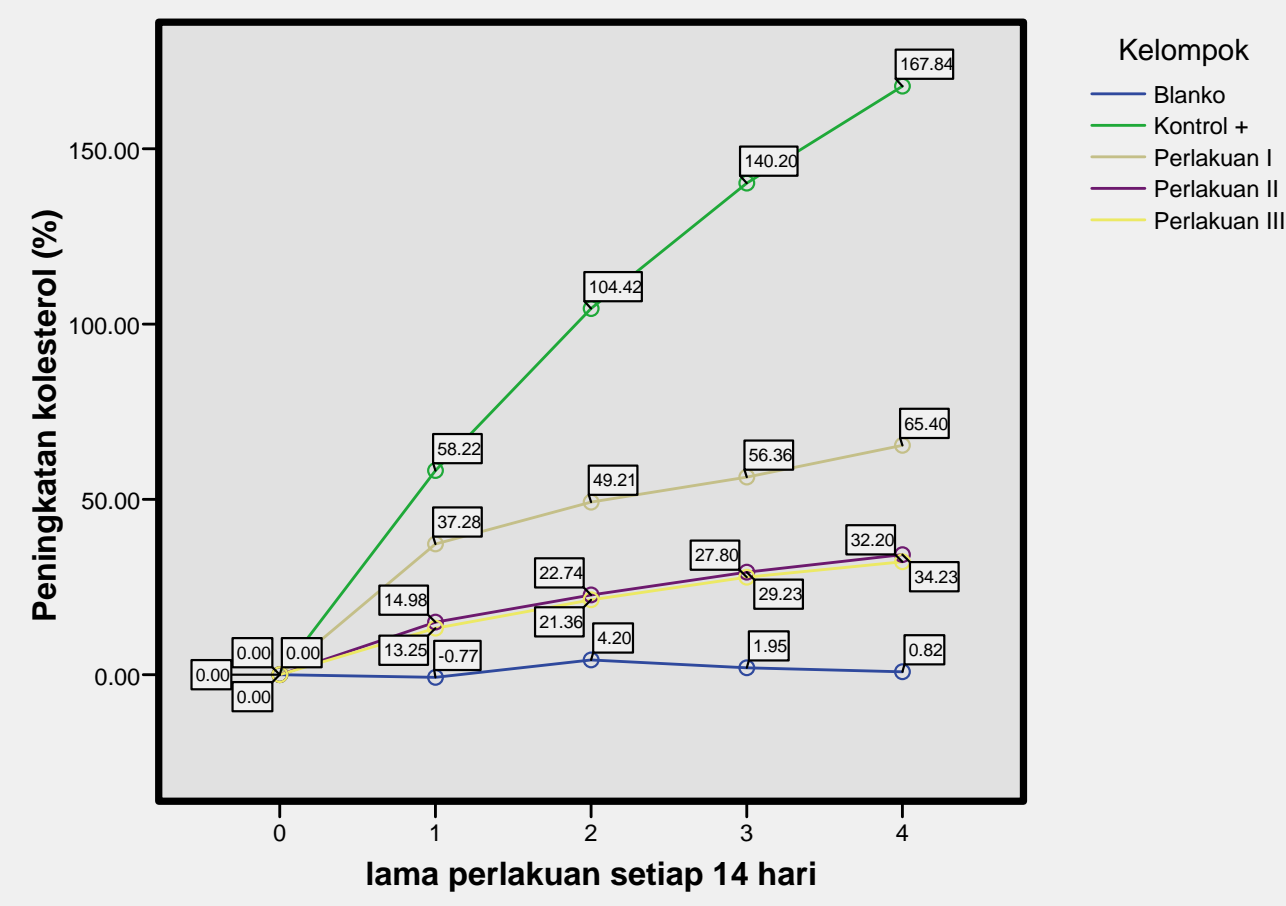

Gambar 1. Grafik persentase peningkatan kolesterol hewan coba

\section{B. PEMBAHASAN}

Untuk melihat apakah ada pengaruh lama (waktu) perlakuan terhadap kadar kolesterol pada masing-masing kelompok, data dianalisis dengan analisis GLM pengukuran berulang.

Tabel 4. merupakan ringkasan perbedaan persentase peningkatan kolesterol antar waktu pada masingmasing kelompok dibandingkan terhadap waktu awal perlakuan (K0).

Berdasarkan tabel 4, tak ada perbedaan yang bermakna $(\mathrm{p}>0.05)$ setiap 14 hari perlakuan pada kelompok blanko yang mendapat diet standar. Hal 
DEWA (Phaleria Macrocarpa Scheff Boerl) TERHADAP PENCEGAHAN PENINGKATAN KOLESTEROL DARAH PADA TIKUS PUTIH JANTAN (Rattus Novergicus) YANG DIBERI DIET LEMAK TINGGI

ini membuktikan bahwa makanan stan- 4\%, serat kasar mini-mum 6\%, Abu dar yang berupa makanan ikan terapung masimum $13 \%$ dan kadar air maksimerk Global feed 555 berupa pelet yang mum 12\% tidak berpengaruh terhadap terdiri dari komposisi: protein kasar peningkatan kolesterol pada hewan minimum: $18 \%$, lemak kasar minimum coba.

Tabel 4. Ringkasan perbedaan persentase peningkatan kolesterol antar waktu selama perlakuan pada masing-masing kelompok perlakuan

\begin{tabular}{|c|c|c|c|c|c|c|}
\hline $\begin{array}{l}\text { Kelompok } \\
\text { perlakuan }\end{array}$ & & $\begin{array}{c}\uparrow K 0 \\
(\%)\end{array}$ & $\begin{array}{c}\uparrow \text { K14 } \\
(\%)\end{array}$ & $\begin{array}{c}\uparrow \mathrm{K} 28 \\
(\%)\end{array}$ & $\begin{array}{c}\uparrow \text { K42 } \\
(\%)\end{array}$ & $\begin{array}{c}\uparrow \mathrm{K} 56 \\
(\%)\end{array}$ \\
\hline \multirow[b]{2}{*}{ blanko } & Rata-rata & 0,00 & $-0,77$ & 4,20 & 1,95 & 0,82 \\
\hline & Std. deviasi & 0,00 & 1,68 & 3,20 & 2,93 & 1,76 \\
\hline \multirow{3}{*}{ kontrol (-) } & Rata-rata & 0,00 & $58,22^{*}$ & $104,42^{*}$ & $140,20^{*}$ & $167,84^{*}$ \\
\hline & Std. deviasi & 0,00 & 6,66 & 12,90 & 12,30 & 14,26 \\
\hline & Rata-rata & 0,00 & $37,28^{*}$ & $49,21^{*}$ & $56,35^{*}$ & $65,40^{*}$ \\
\hline \multirow[t]{2}{*}{ Perlakuan I } & Std. deviasi & 0,00 & 5,28 & 5,83 & 6,09 & 9,82 \\
\hline & Rata-rata & 0,00 & $14,98^{*}$ & $22,74^{*}$ & $29,23^{*}$ & $34,23^{*}$ \\
\hline \multirow[t]{2}{*}{ Perlakuan II } & Std. deviasi & 0,00 & 4,44 & 4,92 & 6,53 & 7,37 \\
\hline & Rata-rata & 0,00 & $13,26^{*}$ & $21,36^{*}$ & $27,81^{\star}$ & $32,19^{*}$ \\
\hline Perlakuan III & Std. deviasi & 0,00 & 1,88 & 2,44 & 2,77 & 2,83 \\
\hline
\end{tabular}

Pada kelompok II (kontrol -), tase peningkatan kolesterol hewan coba terlihat peningkatan kolesterol yang antar kelompok. yang signifikan selama perlakuan baik pada 14 hari pertama sampai 14 hari ke empat (K56) $(\mathrm{p}<0,05)$. Dalam hal ini menunjukan bahwa penambahan $18 \%$ lemak sapi, $10 \%$ kuning telur itik dan $2 \%$ kolesterol murni dapat meningkatkan kadar kolesterol pada hewan coba. Hal yang sama juga terlihat pada kelompok perlakuan I, II dan III.

Berdasarkan tabel 5, terjadi peningkatan kolesterol pada kelompok II / kontrol (-) yang mendapat diet lemat tinggi (DLT) dan $1 \mathrm{ml}$ aquades berturutturut 58,$22 ; 104,42 ; 140,20$ dan $167,94 \%$ setelah 14 hari pertama, kedua, ketiga dan ke empat. Pada kelompok III (perlakuan I) yang men-dapat DLT dan $1 \mathrm{ml}$ infus yang setara $97 \mathrm{mg}$ MD

Untuk mengamati perbedaan pengaruh pemberian infus mahkota dewa (perlakuan) terhadap peningkatan kolesterol pada antar kelompok perlakuan, data dianalisis dengan menggunakan one-way anova. Tabel 5 merupakan ringkasan perbedaan persenkering terjadi peningkatan kolesterol berturut-turut 38,$28 ; 49,21,56,35$ dan $65,40 \%$ setelah 14 hari pertama, kedua, ketiga dan ke empat. Pada kelompok IV (perlakuan II) yang mendapat DLT dan $1 \mathrm{ml}$ infus yang setara $194 \mathrm{mg}$ MD kering terjadi peningkatan kolesterol berturut-turut 14,$98 ; 22,74,29,23$ dan 
34,230\% setelah 14 hari pertama, kedua, ketiga dan ke empat.

Tabel 5. Ringkasan ringkasan perbedaan persentase peningkatan kolesterol hewan coba antar kelompok perlakuan

\begin{tabular}{|c|c|c|c|c|c|c|}
\hline $\begin{array}{l}\text { Kelompok } \\
\text { perlakuan }\end{array}$ & & $\begin{array}{l}\uparrow \mathrm{KO} \\
(\%)\end{array}$ & $\begin{array}{c}\uparrow \mathrm{K} 14 \\
(\%)\end{array}$ & $\begin{array}{c}\uparrow \mathrm{K} 28 \\
(\%)\end{array}$ & $\begin{array}{c}\uparrow \mathrm{K42} \\
(\%)\end{array}$ & $\begin{array}{c}\uparrow \mathrm{K56} \\
(\%) \\
\end{array}$ \\
\hline \multirow{3}{*}{ blanko } & Rata-rata & 0,00 & $-0,77$ & 4,20 & 1,95 & 0,82 \\
\hline & Std. deviasi & 0,00 & 1,68 & 3,20 & 2,93 & 1,76 \\
\hline & Rata-rata & 0,00 & 58,22 & 104,42 & 140,20 & 167,84 \\
\hline \multirow[t]{2}{*}{ kontrol (-) } & Std. deviasi & 0,00 & 6,66 & 12,90 & 12,30 & 14,26 \\
\hline & Rata-rata & 0,00 & $37,28^{*}$ & $49,21^{*}$ & $56,35^{*}$ & $65,40^{*}$ \\
\hline \multirow[t]{2}{*}{ Perlakuan I } & Std. deviasi & 0,00 & 5,28 & $5,83^{*}$ & 6,09 & 9,82 \\
\hline & Rata-rata & 0,00 & $14,98 * \#$ & $22,74^{*} \#$ & $29,23^{*} \#$ & $34,23^{*} \#$ \\
\hline \multirow[t]{2}{*}{ Perlakuan II } & Std. deviasi & 0,00 & 4,44 & 4,92 & 6,53 & 7,37 \\
\hline & Rata-rata & 0,00 & $13,26 * \# \&$ & $21,36 * \# \&$ & $27,81^{*} \# \&$ & $32,19^{*} \# \&$ \\
\hline Perlakuan III & Std. deviasi & 0,00 & 1,88 & 2,44 & 2,77 & 2,83 \\
\hline $\begin{array}{r}\text { Keterangan : } \\
-\quad=\text { berb } \\
-\quad \#=\text { be } \\
\text { - } \quad \&=\text { tic }\end{array}$ & $\begin{array}{l}=6 \\
\text { a bermakna } \\
\text { da bermak }\end{array}$ & 1 & xuan I ( & ,05) pa & ktu y & ama \\
\hline
\end{tabular}

Selanjutnya pada kelompok V (perlakuan III) yang mendapat DLT dan $1 \mathrm{ml}$ infus yang setara $388 \mathrm{MD}$ kering terjadi peningkatan kolesterol berturutturut 13,$26 ; 21,36 ; 27,81$ dan $32,19 \%$ setelah 14 hari pertama, kedua, ketiga dan ke empat.

Hasil analisis statistik one-way anova terdapat perbedaan yang bermakna dalam hal peningkatan kolesterol antara kelompok perlakuan I, II dan III terhadap kontrol (-) dimana kelompok perlakuan meningkatkan kolesterol lebih kecil. Peningkatan persentase yang lebih kecil ini pada kelompok perlakuan diduga akibat pemberian infus MD. Sebagaimana yang dilaporkan Saufi, ${ }^{(9)}$ buah mahkota dewa mengandung senyawa lignans pinoresinol, lariciresinol, dan matairesinol. Disamping itu buah mahkota dewa juga mengandung senyawa flavonoid dan saponim. ${ }^{(10)}$
Flavonoid adalah senyawa yang larut dalam air yang bersifat antioksidan. Senyawa ini banyak terdapat pada buah-buahan dan sayuran. Berbagai efek dari flavonoid cukup banyak dilaporkan oleh peneliti antara lain sebagai antiinflamsi, antialegi, anti viral dan anticarsinogenik. ${ }^{(11)}$ Roza dan kawan-kawan telah membuktikan bahwa flavonoid yang berasal citrus dapat menurunkan kolesterol $20-30 \%$ pada pasien yang hiperkolestero-lemik. ${ }^{(12)}$

Terdapat perbedaan yang signifikan terhadap peningkatan kolesterol antara kelompok IV dan V yang mendapat 194 dan $388 \mathrm{mg}$ MD dibanding peningkatan kolesterol pada kelompok III yang mendapat $97 \mathrm{mg}$ MD dimana pada kelompok IV dan V peningkatan kolesterolnya jauh lebih kecil dibanding kelompok III. Hal ini dapat disebabkan jumlah kandungan senyawa aktif yang berbeda akibat konsentrasi yang berbeda dari infus MD yang diberikan. 
Tidak terdapat perbedaan yang bermakna pada peningkatan kolesterol antara kelompok IV dengan kelompok $\mathrm{V}$, meskipun dosis MDnya 1 berbanding 2. Hal ini bisa jadi disebabkan sudah tercapainya efek penghambatan yang maksimum pada dosis $194 \mathrm{mg}$.

Kecilnya persentase peningkatan kolesterol pada kelompok perlakuan baik pada kelompok PI, PII dan PIII dibanding kelompok II (control -) yang tidak mendapatkan infus MD, menunjukan bahwa infus MD dapat menghambat peningkatan kolesterol pada hewan coba yang di induksi dengan diet lemak tinggi.

\section{Kesimpulan}

1. Pemberian $1 \mathrm{ml}$ infus yang mengandung 97, 194 dan 388 mg mahkota dewa dapat menghambat peningkatan kolesterol total pada hewan coba yang diberi diet lemak tinggi.

2. Penghambatan maskimum terdapat pada pemberian 194 mg mahkota dewa.

3. Tidak terdapat perbedaan efek penghambatan kolesterol antara dosis 194 dengan 388 mg pada hewan coba.

\section{Saran}

1. Perlu dilakukan penelitian lebih lanjut utuk melihat efek preventiv dan kuratif pemberian buah mahkota dewa terhadap profil lipid yang lain pada hewan coba.

2. Perlu ditelusuri senyawa apa yang tedapat pada buah mahkota dewa yang bertanggung jawab terhadap penghambatan kolesterol pada hewan coba.

\section{KEPUSTAKAAN}

1. Thomas A. Gaziano, MD, MSc, Asaf Bitton, MD, Shuchi Anand, MD, Shafika Abrahams-Gessel, MS, and Adrianna Murphy: Growing Epidemic of Coronary Heart Disease in Low- and Middle-Income Countries. Curr Probl Cardiol. 2010 February; 35(2): 72-115.

2. Depkes RI,. Pusat Data Departemen Keshatan RI, Jakarta. 2005.

3. Centers for Disease Control and Prevention (CDC). Vital signs: prevalence, treatment, and control of high levels of lowdensity lipoprotein cholesterol-United States, 1999-2002 and 2005-2008. MMWR Morb Mortal Wkly Rep. 2011 Feb 4;60(4):109-14.

4. Maratani, A: Pengaruh Pemberian Rebusan Buah Mahkota Dewa (Phaleria macrocarpa) Terhadap Produksi ReactiveOxygen Intermediate (ROI) Makrofag Mencit Balb/c yang diinfeksi Salmonella typhimurium. Karya Ilmiah Sarjana Kedokteran FK UNdip Semarang. 2006.

5. Rostinawati, $\mathrm{T}$ : uji aktivitas hasil penyarian biji mahkota dewa (phaleria macrocarpa [scheff.] terhadap beberapa mikroba penyebab infeksi kulit: Fakultas Farmasi Universitas Padjadjaran, Bandung. 2007.

6. Rini, E $\mathrm{P}$,. Pengaruh infusa daging buah mahkota dewa 
(phaleria macrocarpa (scheff. Boerl) terhadap penurunan glukosa darah kelinci jantan new zealand yang dibebani glukosa oral: Skripsi Fakultas Farmasi Muhammadiyah, Surakarta. 2009.

7. Widyasari, A; Yudanti Riastiti, Indwiani Astuti, Rina Susilowati, Harijadi. Efek biji mahkota dewa terhadap ekspresi caspase3 a ktif pada cel line $\mathrm{Ca}$ colon WiDr: Berkala llmu Kedokteran Vol. 38, No. I , Maret 2006: 2429.

8. Harmanto, Ning.. Mengusir Kolesterol dengan Mahkota Dewa. Agromedia Pustaka. 2008.

9. Saufi, A: Lignans in Phaleria macrocarpa (Scheff. Boerl). and in Linum flavum var. compactum L. Dissertation. Mathematisch-

Naturwissenschaftlichen.
Fakultät der Heinrich-HeineUniversität Düsseldorf. 2007.

10. Rohyani, Y. Penentuan Kandungan Flavonoid dari Ekstrak Metanol Daging Buah Mahkota Dewa (Phaleria macrocarpa Scheff Boerl ): Jurnal Logika Edisi : Volume 5Nomor 1-Agustus, 2008.

11. Nijveld, Robert $\mathrm{J}$ t, Els van Nood, Danny EC van Hoorn, Petra G Boelens, Klaske van Norren, and Paul AM van Leeuwen, 2001. Flavonoids: a review of probable mechanisms of action and potential applications. Am J Clin Nutr 2001;74:418-25.

12. Roza, James M., CN; Zheng Xian-Liu, PhD; Najla Guthrie. Effect of citrus flavonoids and tocotrienols on serum cholesterol levels in hypercholesterolemic subjects. Alternative therapies, nov/dec 2007, vol. 13 , no. 6 ; 44 - 8 . 